\title{
Camelia Stan, $O$ sintaxă diacronică a limbii române vechi, Editura Universității din București, București, 2013, 371 p.
}

\author{
Mihaela Gheorghe* \\ Faculty of Letters, "Transilvania” University of Brașov, Bd. Eroilor 29, 500036 Brașov, Romania \\ "Iorgu Iordan - Al. Rosetti" Institute of Linguistics, Calea 13 Septembrie 13, 050711 Bucharest, Romania
}

Lately, in the context of Romanian linguistics, one may notice a turn of perspective, shaped as a switch of interest from synchronic to diachronic investigation of language. The concern for diachronic studies, for decades accounted as a constant preoccupation by a (increasingly) reduced number of researchers, appears to exhibit a new spirit today. More and more researchers who used to be committed to synchronous studies or young doctoral students re-evaluate through their work a language material until recently ignored or engage in collective projects of diachronic investigation, contributing to a revival of the linguistic research by confronting the old Romanian linguistic data to a new theoretical apparatus.

In this context, the recent book of Camelia Stan, $O$ sintaxă diacronică a limbii române vechi $[A$ diachronic syntax of Old Romanian], is a double scientific event: it is an interesting work, providing extensive coverage to a gap in the literature, and it is a comprehensive and detailed description of the syntactic structures of old Romanian $\left(16^{\text {th }}-18^{\text {th }}\right.$ centuries); the constant connection of the old data to the current state of language makes this book necessary for both Romanian and foreign linguistics.

The description of the most representative forms and structures of old Romanian, together with their grammaticalization processes are valuable sources of information for researchers of both Romanian and foreign syntax, regardless the theoretical framework they are committed to. The typological perspective adopted here, which parallels the diachronic one contribute to revealing the most important features of Romanian in both Romance and Balkan context.

Innovation and originality of the work lies not only in the description and the interpretation of data (based on a rich corpus, investigated with high accuracy), but also in the author's power to sum up (des- pite the qualification of superficiality that the author modestly attributed to it in the introduction) the linguistic features of an extensive period of time in the history of Romanian. Redeeming a rich and comprehensive bibliography, which includes virtually all the Romanian references relevant to the theme, and also a great number of titles from both classic and modern international bibliography, Camelia Stan formulates profound and original considerations based on her direct investigation of the language structures, and face them with views that were previously expressed by other researchers or by herself.

The complex architecture of the volume allows reading according to different proficiency levels. The reader exclusively interested in a certain issue of syntax can search for the paragraphs dedicated to that issue and find numerous examples that illustrate it; the introductory level reader or the initiated one will find here information of impeccable scientific accuracy, regarding the most difficult problems of Romanian syntax, which are addressed through a language material belonging to old Romanian. Linguists, or readers who are authorized to access all the reading levels are offered excellent theoretical synthesis and interpretative solutions rigorously substantiated (basically, every claim and every demonstration is supported by ample reference to previous research).

The first chapter has a synthetic character and handles the interference of foreign syntactic patterns (Slavonic and scholar Latin, especially) with the syntactic patterns of spoken Romanian. The author will return throughout the paper on the features sketchily inventoried here, indicating, whenever necessary, the parentage of a certain phenomenon or the interference that can be inferred from the interpretation of the data provided by the corpus (the examples are always discussed in terms of the foreign model, if

*Email address:m.gheorghe@unitbv.ro. 
they belong to a translated work, or in terms of the geographic placement, if the source is an original text).

The second chapter is dedicated to the nominal phrase and, besides a detailed description of its maximal projection and of its constituent inventory, it discusses themes that are crucial for the understanding of the syntax of Romanian in the context of Romance: determiners, quantifiers and case marking, which are topics that the author has previously reflected upon and about which has published numerous studies in the late years. The evolution of the forms and of the determiner patterns is illustrated in detail, showing how their functions have changed since the old stage of Romanian, what were the reasons that led to the elimination of certain positions, and what determined the settlement of the contemporary patterns.

The third and largest chapter deals with sentence structure in old Romanian. As the author shows in the preliminary section, although the constituents are designated in traditional terms, by their syntactic functions, the description is organized in a modern framework. The chapter discusses the predicative syntactic positions (subjective predicative complement, objective predicative complement, small clauses), argumental positions (subject, direct object, secondary object, indirect and prepositional object), followed by adjuncts (situative adjuncts, modals, instrumental, associative, etc.). Special sections of the chapter are dedicated to passive constructions and to the quantifiers of the verb. The description of each syntactic position is considered in terms of its governors and of the inventory of realizations (including clausal), richly illustrated with chronologically-organized sequences of corpus. The paragraphs of conclusions that close each syntactic description provide excellent summaries on their defining characteristics and also information on the origin, the evolution and the frequency of specific patterns.

The fourth chapter deals with non-finite verb forms, discussing their special syntax, especially the subject matter, but also taking into account some other features of the VP with non-finite head.

The following chapters focus on the internal structure of the adjectival and adverbial phrase, on their complements; correlations with other chapters that included the adjective and the adverb in the description are made.

Chapters 7-12 cover a range of special syntax issues: relative and interrogative sentences, coordination, negation, comparison, apposition and syntactic ambiguities, anacoluthon, sequence of tenses. Punctuation (another topic in which the author is a highly authoritative voice) is addressed in a separate chapter in which it is shown that few modern punctuation elements are found in old age.

Without resuming the conclusions at the end of each section or chapter, and through an effort of synthesis for which only a fine expert in syntax, doubled by a passionate researcher of the ancient texts can be fit to accomplish, Camelia Stan manages to make in the chapter of final conclusions an overall characterization old Roman syntax from the perspective of (i) the historical and the cultural context in which the texts are issued; (ii) the parametric features attested as early as the $16^{\text {th }}$ century; (iii) the most representative stages for the shaping of the typological features of Romanian. Thus, after being convincingly illustrated in the thirteen chapters of the book, the ideas in this section seem to fall off naturally, but they are the result of the passionate labour of one of the most important and rigorous linguist, a model of erudition, insight and modesty.

Camelia Stan's book is a reference work, on one hand the result of a huge effort to elaborate a modern single authored syntax of an extended period of time, without the benefit of comprehensive bibliographic support, and on the other hand the result of an effort to collect an effective linguistic material, which is both impressive in size and highly relevant for illustrating the theoretical topics under investigation. 